\title{
Stability of thyroxine and triiodothyronine in biological fluids
}

\author{
LYNN NYE, T. H. YEO, VIVIAN CHAN 1 , D. GOLDIE ${ }^{2}$, AND J. LANDON 3 \\ From the Department of Chemical Pathology, St Bartholomew's Hospital, London ECI
}

SYNOPSIS The stability of thyroxine and triiodothyronine in serum has been investigated.

Apparent levels of total thyroxine, as determined by two different protein-binding assays employing thyroxine-binding globulin as the binding protein, increased significantly in serum and plasma samples stored at room temperature and were significantly lower in haemolysed samples. Values did not change significantly in samples stored at $4^{\circ} \mathrm{C}$, nor in samples stored at room temperature when determined by radioimmunoassay. Total triiodothyronine levels, as determined by radioimmunoassay, fell slightly on storage.

Failure to appreciate the effect of storing samples at room temperature on apparent levels of total thyroxine, as determined by some protein-binding assays, could lead to an incorrect assessment of thyroid status.

There has been a rapid increase in demand for hormone determinations during recent years (Landon et al, 1974). Such assays are often technically complex and many require the use of isotope counting equipment. Thus, at present, many laboratories send some samples to specialized analytical centres. This has the disadvantage that several days may elapse vetween sample collection and assay, especially if there are postal delays or the sample arrives at the weekend. In addition, samples may be stored for several days at room temperature, sometimes unseparated or haemolysed, before despatch.

Thyroid disorders are among the commonest endocrine abnormalities encountered in clinical practice and, for this reason, the stability of thyroxine $\left(T_{4}\right)$ and triiodothyronine $\left(T_{3}\right)$ has been studied in blood samples obtained and stored under a variety of conditions similar to those that might be encountered in normal clinical practice. The effect of sample storage in the light and in the dark has also been investigated.

\section{Materials and Methods}

PRELIMINARY INVESTIGATION OF THE STABILITY OF TOTAL T4 AND TOTAL T3

Blood samples from each of six euthyroid subjects were divided into five aliquots, which were treated and stored for 48 hours under the conditions listed

Received for publication 17 March 1975. in the table. Total $T_{3}$ levels were determined by radioimmunoassay, total $T_{4}$ levels by a proteinbinding assay (Thyopac 4), and the capacity to bind labelled $\mathrm{T}_{3}$ was also assessed (THUT).

\section{COMPARISON OF THE EFFECT OF STORAGE ON APPARENT SERUM TOTAL T4 AND \\ PROTEIN-BOUND IODINE LEVELS}

Twenty millilitres of blood from each of two euthyroid subjects was allowed to clot at room temperature and the serum was separated and stored at room temperature in the light. Samples of the serum were removed after 0,3 , and 6 days and stored at $-20^{\circ} \mathrm{C}$ before measurement of proteinbound iodine and total $\mathrm{T}_{4}$ by the Thyopac $4 \mathrm{kit}$.

\section{COMPARISON OF THE EFFECT OF STORAGE}

ON APPARENT SERUM TOTAL T 3 AND T4

LEVELS AS DETERMINED BY DIFFERENT

METHODS

Blood samples from three euthyroid subjects and from one clinically hyperthyroid patient were allowed to clot at room temperature, and the serum from each was divided into two aliquots, one of which was stored at room temperature and the other at $4^{\circ} \mathrm{C}$. Samples were removed from each aliquot

'Present address: University Department of Medicine, Queen Mary Hospital, Pokfulam Road, Hong Kong.

2Present address: Department of Pathology, Southmead General Hospital, Bristol BS10 5NB.

${ }^{3}$ Requests for reprints to J. Landon. 


\begin{tabular}{|c|c|c|c|c|c|c|c|c|c|c|}
\hline \multirow[t]{3}{*}{ Subject } & \multicolumn{5}{|c|}{ Total $T_{4}(\mathrm{nmol} / \mathrm{l})$} & \multicolumn{5}{|c|}{ Total $T_{\mathrm{s}}(\mathrm{nmol} / \mathrm{l})$} \\
\hline & \multicolumn{5}{|c|}{ Aliquot } & \multicolumn{5}{|c|}{ Aliguot } \\
\hline & $I$ & 2 & 3 & 4 & 5 & $\bar{I}$ & 2 & 3 & 4 & 5 \\
\hline $\begin{array}{l}1 \\
2 \\
3 \\
4 \\
5 \\
6\end{array}$ & $\begin{array}{r}71 \\
100 \\
75 \\
171 \\
86 \\
116\end{array}$ & $\begin{array}{r}88 \\
142 \\
80 \\
197 \\
100 \\
165\end{array}$ & $\begin{array}{r}93 \\
131 \\
97 \\
187 \\
103 \\
144\end{array}$ & $\begin{array}{r}52 \\
54 \\
63 \\
165 \\
66 \\
108\end{array}$ & $\begin{array}{r}79 \\
116 \\
85 \\
200 \\
97 \\
151\end{array}$ & $\begin{array}{l}1 \cdot 77 \\
2.25 \\
1.92 \\
2.58 \\
2.22 \\
2.54\end{array}$ & $\begin{array}{l}1.70 \\
1.77 \\
1.69 \\
2.53 \\
1.96 \\
2.26\end{array}$ & $\begin{array}{l}1.73 \\
1.86 \\
1.57 \\
2.60 \\
2.15 \\
2.40\end{array}$ & $\begin{array}{l}1.78 \\
1.82 \\
1.80 \\
3.05 \\
1.99 \\
2.41\end{array}$ & $\begin{array}{l}1.73 \\
1.86 \\
1.71 \\
2.73 \\
2.03 \\
2.24\end{array}$ \\
\hline $\begin{array}{l}\text { Mean } \\
\mathbf{P}\end{array}$ & 103 & $\begin{array}{l}129 \\
0.01\end{array}$ & $\begin{array}{l}126 \\
0.01\end{array}$ & $\begin{array}{c}85 \\
0.02\end{array}$ & $\begin{array}{l}121 \\
0.01\end{array}$ & $\begin{array}{l}2 \cdot 21 \\
-\end{array}$ & $\begin{array}{l}1.99 \\
0.02\end{array}$ & $\begin{array}{l}2.05 \\
0.05\end{array}$ & $\begin{array}{l}2 \cdot 14 \\
0.2\end{array}$ & $\begin{array}{l}2.05 \\
0.1\end{array}$ \\
\hline
\end{tabular}

Table Effect of various storage conditions on apparent total $T_{4}$ levels as determined by the Thyopac 4 kit and total $T_{\mathrm{a}}$ levels by radioimmunoassay

Blood was collected into lithium heparin containing tubes (approximately $10 \mathrm{u}$ lithium heparin/ml of blood) for aliquots $1-4$, and into a plain glass tube for aliquot 5 , and treated as follows:

Aliquot 1 The plasma was separated immediately and stored at $-20^{\circ} \mathrm{C}$.

Aliquot 2 The plasma was separated immediately and stored at room temperature, in the light.

Aliquot 3 The blood was stored at room temperature in the light.

Aliquot 4 The blood was haemolysed by repeated passage of the whole blood through a narrow syringe needle; the plasma was separated and stored at $-20^{\circ} \mathrm{C}$.

Aliquot 5 The blood was allowed to clot and stored unseparated at room temperature in the light.

After two days aliquots 3 and 5 were separated and the total $T_{4}$, total $T_{3}$, and THUT levels were measured in all aliquots.

at intervals and stored at $-20^{\circ} \mathrm{C}$. Total $\mathrm{T}_{4}$ levels were determined by the Thyopac $4 \mathrm{kit}$, by a resin protein binding assay, and by a radioimmunoassay. Total $T_{3}$ levels were determined by radioimmunoassay.

INVESTIGATION OF THE EFFECT OF LIGHT ON THE STABILITY OF TOTAL T4

Blood samples were collected from 15 patients and allowed to clot at room temperature. After separation, each serum was divided into three aliquots, one of which was stored at $-20^{\circ} \mathrm{C}$. The other two were stored at room temperature for 14 days, one in the light, the other in the dark, and then stored at $-20^{\circ} \mathrm{C}$ until assayed by the Thyopac 4 kit.

\section{ASSAYS}

\section{Triiodothyronine}

A modification of the method of Mitsuma et al (1971) was employed using non-extracted serum and a goat antibody raised against a $\mathrm{T}_{\mathbf{3}}$-human serum albumin conjugate. 8-Anilino-l-naphthalene sulphonic acid (ANS) was used to block the binding sites of thyroxine-binding globulin (TBG) and the antibody-bound and free fractions were separated with methyl cellulose coated charcoal. The "withinbatch' coefficient of variation was $4.4 \%$ as determined by 10 simultaneous analyses of a single pooled serum.

\section{Thyroxine}

Total $\mathbf{T}_{4}$ was estimated by three methods:

(1) A protein-binding assay based on the use of
TBG (Thyopac $4 \mathrm{kit}$ ) was performed according to the manufacturer's instructions. $T_{4}$ was extracted from the sample by addition of ethanol and equilibrated with TBG and labelled $T_{4}$. Protein-bound and free $\mathbf{T}_{4}$ were separated by equilibration with adsorbent granules. The 'within-batch' coefficient of variation was $8.9 \%$ as determined by 10 simultaneous analyses of a single pooled serum.

(2) A TBG-binding assay (resin assay) was used, which was a modification of the method described by Murphy (1965) and employed an anion exchange resin, $\mathrm{Ag} 1 \times 2$ (Biorad Laboratories), to separate the bound and free fractions. A correction for the efficiency of ethanol extraction was made for each sample. The 'within-batch' coefficient of variation was $6.2 \%$ as determined by 10 simultaneous analyses of a single pooled serum.

(3) A modification of the radioimmunoassay method of Chopra (1972) was employed, using nonextracted serum and a rabbit antibody raised against a $\mathbf{T}_{4}$-bovine serum albumin conjugate. ANS was used to block the binding sites of TBG, and the antibody-bound and free fractions were separated by a second antibody technique. The 'within-batch' coefficient of variation was $2.4 \%$ as determined by 10 simultaneous analyses of a single pooled serum.

\section{Thyroid hormone uptake test (THUT)}

The capacity of the samples to bind thyroid hormones was assessed by the Thyopac 4 kit (Radiochemical Centre, Amersham), performed according to the manufacturer's instructions. The samples were incubated with labelled $T_{3}$, and the proteinbound and free $T_{3}$ were then separated by equilibration with absorbent granules. 


\section{Protein-bound iodine}

This was estimated by a Technicon Autoanalyser Mark I method with a 'within-batch' coefficient of variation of $4.0 \%$ (Chan, 1973).

\section{Results}

PRELIMINARY INVESTIGATION OF THE

STABILITY OF TOTAL T4 AND TOTAL T3

The results are summarized in the table in which the values obtained for aliquot 1 (heparinized plasma which had been separated and stored at $-20^{\circ} \mathrm{C}$ immediately after collection) from each subject are used as a reference. Storage of plasma or whole blood, whether clotted or heparinized, for $\mathbf{4 8}$ hours at room temperature resulted in a significant increase of apparent $\mathrm{T}_{4}$ levels (approximately $20 \%$ ) as determined by the Thyopac $4 \mathrm{kit}$. The presence of haemolysis (aliquot 4) resulted in a significant decrease in apparent $T_{4}$ values of some $17 \%$. Storage of plasma samples at room temperature caused small but significant losses in apparent total $\mathrm{T}_{3}$ levels from mean value of 2.21 to $1.99 \mathrm{nmol} / \mathrm{l}$ (aliquot 2). Similar decreases were also observed in aliquots 3 and 5 , but haemolysis had no significant effect.

Storage at room temperature and haemolysis had no significant effect on the capacity of the aliquots to bind labelled $T_{3}$, the results of the THUT assays on aliquots $2,3,4$, and 5 ranging from 98.3 to $101.2 \%$ of aliquot 1 .

\section{COMPARISON OF THE EFFECT OF STORAGE}

ON APPARENT SERUM TOTAL T 4 AND

PROTEIN-BOUND IODINE LEVELS

After six days' storage at room temperature the apparent serum total $T_{4}$ levels of two subjects, as determined by the Thyopac 4 assays, increased from 91 to 121 and from 98 to $122 \mathrm{nmol} / \mathrm{l}$. There was no corresponding increase in protein-bound iodine values, which remained at 66 and $58 \mathrm{nmol} / 1 \mathrm{re}-$ spectively.

\section{COMPARISON OF THE EFFECT OF STORAGE} ON APPARENT SERUM TOTAL T3 AND T4 LEVELS AS DETERMINED BY DIFFERENT METHODS

All serum samples stored at room temperature showed a continuous rise in apparent $T_{4}$ content when determined by the Thyopac 4 and by the resin assay. Thus, with the former, all three euthyroid subjects, who had normal initial values, would have been diagnosed as thyrotoxic on the values obtained after storage of the samples at room temperature for two weeks. The resin assay showed less dramatic increases, but nonetheless levels increased into the thyrotoxic range in two of the three euthyroid

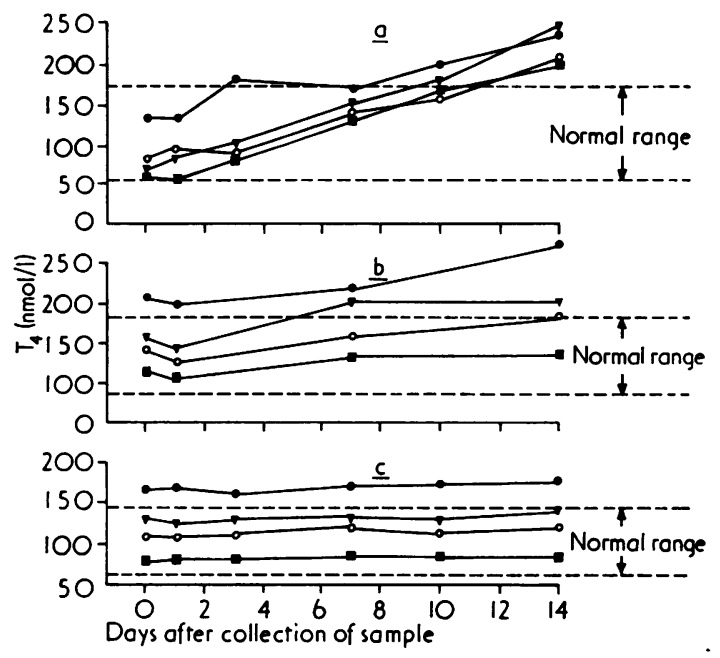

Fig 1 Apparent $T_{4}$ levels measured by (a) Thyopac 4, (b) resin-assay, and (c) radioimmunoassay of one clinically hyperthyroid patient $(O)$ and three euthyroid subjects $(\bigcirc \nabla \square)$ after storage at room temperature for various times.

subjects. There was no significant change in $T_{4}$ values when the samples were measured by radioimmunoassay (fig 1). $\mathrm{T}_{4}$ levels remained constant in all samples stored at $4^{\circ} \mathrm{C}$ as determined by all three assays.

The apparent $T_{3}$ levels in the serum of all subjects, as measured by radioimmunoassay, fell when stored either at room temperature or at $4^{\circ} \mathrm{C}$. Thus, after one week at room temperature the mean $\mathrm{T}_{3}$ value had decreased from an initial level of $2 \cdot 17 \mathrm{nmol} / 1$ by $19 \%$, while over a similar period at $4^{\circ} \mathrm{C}$ the individual levels had decreased by between 12 and $15 \%$.

\section{INVESTIGATION OF THE EFFECT OF LIGHT}

ON THE STABILITY OF TOTAL T 4

Similar results were obtained from samples stored in the light and in the dark. There was an increase in the apparent total $\mathbf{T}_{\mathbf{4}}$ levels of all 15 samples after storage at room temperature for 14 days when compared with the control sample stored at $-20^{\circ} \mathrm{C}$. Figure 2 shows that the increase varied considerably from sample to sample; however, neither the actual nor the percentage increase was related to the initial total $\mathrm{T}_{4}$ levels.

\section{Discussion}

The most important finding in the present study is that the apparent total $T_{4}$ levels in either plasma or serum samples stored at room temperature increase 


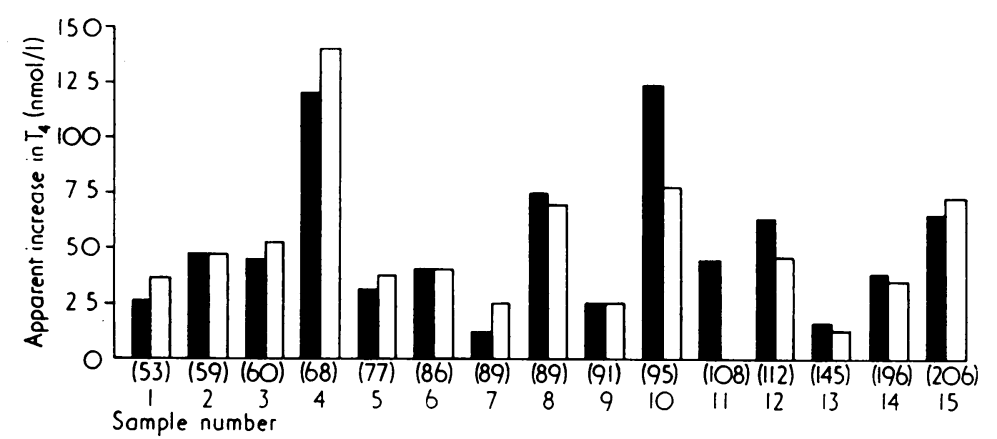

Fig 2 Apparent increase in $T_{4}$ levels after storage at room temperature for 14 days in the dark and in the light $\square$. The values of the control samples are given in parentheses at the base of each pair of columns. when measured by two different protein-binding assays, and that this increase varies considerably from sample to sample. No increase is observed when $\mathrm{T}_{4}$ levels are measured by radioimmunoassay or when the protein-bound iodine is determined, indicating that $\mathrm{T}_{4}$ itself is stable at room temperature and that the increase observed in the protein-binding assays is an artefact. Storage at $4^{\circ} \mathrm{C}$ provides a simple way of preventing this phenomenon but is not always possible, especially when samples are sent by post. Thus, misdiagnosis could easily occur due to hypothyroid values increasing into the euthyroid range or euthyroid values rising into the thyrotoxic range.

Other authors have observed similar increases in total $\mathrm{T}_{4}$ levels after storage when measured by protein-binding assays. However, in contrast to this study, Watson and Lees (1973) and Badman and Platten (1973) suggest that the levels also increase in samples stored at $4^{\circ} \mathrm{C}$ when measured by the Thyopac 4 kit. The results of Frings and Hochholzer (1973), obtained using a protein-binding assay, agree with those of the present study.

Since the efficiency of ethanol extraction could increase after storage at room temperature, the extraction procedure was monitored by the addition of a trace amount of ${ }^{125} \mathrm{I}_{-} \mathrm{T}_{4}$ to each serum sample before analysis. There was no increase in the recovery of the label. It was also possible that $\mathbf{T}_{4}$ might be more unstable when stored in the light, therefore the total $\mathrm{T}_{4}$ content of samples stored under conditions of light and dark was compared. No differences were observed.

The results suggest that at room temperature $T_{4}$ is stable, but that something is generated which interferes in assays employing TBG but not in more specific radioimmunoassays. The nature of this interfering substance was not investigated. It is ethanol extractable since both TBG-binding assays employ this as an initial step. Previous reports have shown that ethanol extracts obtained by the pro- cedures described in this report contain both proteins (Goldie et al, 1974) and an unidentified substance thought to be a phospholipid (Irvine, 1974). One or both of these could interfere either by binding $\mathrm{T}_{4}$ or by inhibiting the reaction between $\mathrm{T}_{4}$ and TBG or the separating agent. Irvine found a substance present in ethanol extracts of serum which bound $T_{4}$ and thus caused a decrease in apparent $T_{4}$ levels. In the present study, however, we observed a progressive increase in apparent total $\mathrm{T}_{4}$ levels on storage. It seems unlikely that the interfering substance would have the same effect on the resin and the absorbent granule separating agents, therefore inhibition of the reaction between $T_{4}$ and the binding protein seems the most probable explanation. Recently, Rootwelt (1975) has shown that there is a correlation between the increase in non-esterified fatty acids, which occurs on storage of blood samples at room temperature, and total $T_{4}$ levels measured by proteinbinding techniques.

The apparent total $T_{3}$ content of both plasma and serum samples decreased on storage at room temperature and to a lesser extent at $4^{\circ} \mathrm{C}$. Conversion of $T_{3}$ to $T_{4}$ is a possibility but cannot account for the apparent increase in $\mathrm{T}_{4}$ levels, which is approximately 50 times greater than that of $\mathrm{T}_{3}$.

Gross haemolysis led to considerable underestimation of $\mathrm{T}_{4}$ levels by the Thyopac $4 \mathrm{kit}$. This was not due to dilution since the $\mathrm{T}_{3}$ content of the same samples was not decreased significantly.

Radioimmunoassay would appear to be the method of choice for $T_{4}$ since by this method serum levels appear to be stable for at least two weeks at room temperature. Nonetheless, valid results may be obtained by TBG binding methods provided that samples are not haemolysed and are immediately stored at temperatures of $4^{\circ} \mathrm{C}$, or lower, until assayed. Haemolysis appears to have no significant effect on total $T_{3}$ when measured by the radioimmunoassay employed in this study, but prolonged storage of samples either at room temperature or at 
$4^{\circ} \mathrm{C}$ should be avoided since the levels appear to decrease slowly.

We gratefully acknowledge support from the Department of Health and Social Security. The Radiochemical Centre, Amersham kindly supplied the Thyopac 4 kits.

\section{References}

Badman, H. G. and Platten, A. F. (1973). Assessment of a simple technique for the determination of serum thyroxine. Ann. clin. Biochem., 10, 53-56.

Chan, V. (1973). In vitro thyroid function tests with special reference to urinary thyroxine and triiodothyronine assays. Ph.D. thesis. University of London.

Chopra, I. J. (1972). A radioimmunoassay for the measurement of thyroxine in unextracted serum. J. clin. Endocr., 34, 938-947.

Frings, C. S. and Hochholzer, J. M. (1973). Stability of serum thyroxine $\left(T_{4}\right)$ as measured by competitive protein binding methods. Clin. Chem., 19, 680 (Abstract).
Goldie, D. J., Jennings, R. D., and McGowan, G. K. (1974). The estimation of serum thyroxine by competitive binding analysis: a modified method. J. clin. Path., 27, 74-82.

Irvine, C. H. G. (1974). The effect of an ethanol-extractable thyroxine binding substance on the measurement of thyroxine by competitive binding. J. clin. Endocr., 38, 468-475.

Landon, J., Rees, L., and Thorner, M. O. (1974). Clinical biochemistry and endocrinology - the future. Ann. clin. Biochem., 11, 153-155.

Mitsuma, T., Nihei, N., Gershengorn, M. C., and Hollander, C. S. (1971). Serum triiodothyronine: measurements in human serum by radioimmunoassay with corroboration by gas-liquid chromatography. J. clin. Invest., 50, 2679-2688.

Murphy, B. E. P. (1965). The determination of thyroxine by competitive protein-binding analysis employing an anionexchange resin and radiothyroxine. J. Lab. clin. Med., 66, 161-167.

Rootwelt, K. (1975). Specificity of competitive proteinbinding radioassay of serum thyroxine determination. The 7th International Thyroid Conference, Boston, U.S.A. Excerpta med., 361, 8.

Watson, D. and Lees, S. (1973). Comparative study of thyroxine assays employing radio-liquid reagents. Ann. clin. Biochem, 10, 14-22. 